\title{
Addressing the Threat of Uncontrolled Escalation by Means of Conventional Arms Control in Europe
}

\author{
Wolfgang Zellner \\ Senior Research Fellow, Institute for Peace Research \\ and Security Policy, the University of Hamburg, Hamburg, Germany \\ zellner@ifsh.de
}

\begin{abstract}
NATO and Russia have given up on cooperative approaches and returned to deterrence; in parallel, arms control regimes are collapsing or eroding. Any deterrence relationship involves a danger of uncontrolled escalation, aggravated by uncertainty, sub-regional crises and a larger role for nuclear weapons. This article explores the possibilities for addressing these threats by means of sub-regional conventional arms control, combining disengagement with transparency and verification measures. Such an approach would address the real threat, mainly by adapting existing agreements, and would also be inexpensive in financial terms.
\end{abstract}

\section{Keywords}

return of deterrence - collapse of arms control - danger of uncontrolled escalation stabilizing deterrence by conventional arms control - sub-regional arms control disengagement - transparency - verification

Conventional arms control in Europe is in deplorable shape. The Conventional Armed Forces in Europe (CFE) Treaty is politically dead and of fairly limited military use. The urgent modernization of the Vienna Document 2011 on Confidence - and Security-Building Measures (VD11) is blocked by the Russian 
Federation. And apparently, there are plans in the Trump administration to scrap the Open Skies Treaty, an aerial surveillance regime. ${ }^{1}$

The unraveling of the conventional arms control regimes in Europe is taking place against the background of the quick and - if nothing happens - almost complete breakdown of nuclear arms control pushing the world back to the $1960 s$, but with a completely different level of armaments. As Ernest J. Moniz and former U.s. Senator Sam Nunn wrote in a recent article in "Foreign Affairs":

The United States and Russia are now in a state of strategic instability; an accident or mishap could set off a cataclysm. Not since the 1962 Cuban missile crisis has the risk of a U.s.-Russian confrontation involving the use of nuclear weapon been as high as it is today. Yet unlike during the Cold War, both sides seem willfully blind to the peril. ${ }^{2}$

The degradation of the (European) arms control regimes is taking place against the background of worsening political and military relations between Russia and the NAто States. We are witnessing the return of a mutual deterrence scenario coupled with the progressive erosion of the co-operative security policies that were pursued until the early 200os. To be sure: We never had a pure co-operative security scenario, but rather a hybrid mix of cooperative and deterrence elements. However, even this led to an unprecedented reduction of conventional and nuclear weapons in Europe.

Since 2014, we have seen a rapid re-emergence of mutually exclusive threat perceptions. What one side perceives as a military threat is seen by the other side as legitimate defence efforts, and vice versa.

We are observing large military exercises on both sides, in some cases the largest since the end of the Cold War, frequently close to borders and on short notice - so-called snap exercises not covered by the Vienna Document.

1 "I am deeply concerned by reports that the Trump Administration is considering withdrawing from the Open Skies Treaty and strongly urge you against such a reckless action." (Letter by Eliot L. Engel, Chairman of the Committee on Foreign Affairs, U.s. House of Representatives, to Robert C. O'Brien, National Security Adviser, October 7, 2019).

2 Ernest J. Moniz/Sam Nunn, The Return of Doomsday. The New Nuclear Arms Race - and How Washington and Moscow Can Stop It, in: Foreign Affairs, vol. 98, no. 5 (September/ October 2019), p. 151. 
In addition, we are seeing hardening military postures. States are investing more, modernizing and in some cases enlarging their armed forces. Forces are deployed forward, closer to borders. The military postures of the sides are approaching each other.

The issue at stake is not a "large-scale offensive option" of a continental size as formulated in the preamble of the CFE Treaty, but a "surprise attack" or the perception of such an attack in the contact zones between NATO and Russia, particularly in the Baltic and Black Sea regions. Altogether, what we are seeing is not yet a full arms race, but something on the brink of one.

Any deterrence relationship necessarily produces risks and inherently drives escalation. Current developments are increasingly driving the two sides into a security dilemma with inherent worst-case thinking, and there are powerful factors at play that can drive escalation, the three most important of which are as follows:

Sub-regional conflicts have a tremendous potential to escalate regional or even global conflicts. Just imagine a re-escalation of hostilities in Ukraine pushing NATO and Russia into direct or indirect confrontation.

Conventional armed forces are tightly linked to the nuclear dimension through the sides' deterrence postures. Thus, it is more than likely that the collapse of the Intermediate-Range Nuclear Forces (INF) Treaty and of nuclear arms control, in general, will have malign consequences for the conventional deterrence relationship in Europe.

Finally, cyberattacks could play an increasing role in the future. Two features make it particularly difficult to address this kind of attack. On the one hand, cyber attacks could be directed at a broad range of targets, including early warning systems. On the other, it is difficult to attribute this kind of attack to a specific actor, particularly under time pressure.

All three of these escalation drivers are closely interrelated. Moniz/Nunn give an impression of how this interrelationship could work out in a worst-case scenario:

With both sides on high alert, a cyberattack of unknown origin is launched against Russian early warning systems, simulating an incoming air attack against air and naval bases in Kaliningrad. With only minutes to confirm the authenticity of the attack and no ongoing NATO-Russian crisis-management dialogue, Moscow decides it must respond immediately and launches conventional cruise missiles from Kaliningrad bases at NATO's Baltic airfields; NATO also responds immediately, with airstrikes on Kaliningrad. Seeing NATO reinforcements arrive and fearing 
that a NATO ground invasion will follow, Moscow concludes that it must escalate to de-escalate - hoping to pause the conflict and open a pathway for a negotiated settlement on Moscow's terms - and conducts a lowyield nuclear strike on nuclear storage bunkers at a NATO airfield. But the de-escalate calculus proves illusory, and a nuclear exchange begins. ${ }^{3}$

It is remarkable that scenarios of this kind are not discussed by peaceniks, but by highly experienced experts. Sam Nunn was Chairman of the U.s. Senate Armed Services Committee from 1987 to 1995 and in this capacity gained a unique insight into conventional and nuclear deterrence postures.

\section{Options for Addressing the Threat of Uncontrolled Escalation}

Against this background, there are three arms control options to address the danger of an uncontrolled escalation. Each of these options corresponds to different assessments of the situation and different political objectives.

The first option is upgrading existing and creating new measures for risk reduction and incident prevention in a direct and narrow sense. In this area, we are witnessing not only ongoing discussions, in the NATO-Russia Council and within the framework of the OSCE's Structured Dialogue ${ }^{4}$ among others but also the first agreed measures. The Baltic Sea Project Team with nine states and a number of international organizations has agreed on a number of measures safeguarding air safety. This is supplemented by about a dozen bilateral agreements on the Prevention of Incidents On and Over the High Seas between Russia and other states, including the U.s., and the UK.

Despite these initial success stories, there is ample room for improvement. Building on the Structured Dialogue and in parallel to sub-regional initiatives, the OSCE could play an important role in this area, for example by strengthening Chapter III (Risk Reduction) of the Vienna Document or by adopting a Code of Conduct on Incidents Prevention.

3 Moniz/Nunn 2019, ibid., p. 150/151.

4 Based on the decision of the 2016 Hamburg osce Ministerial Council Meeting "From Lisbon to Hamburg. Declaration of the Twentieth Anniversary of the osce Framework for Arms Control" (MC.DEC/4/16, 9 December 2016), the osCE conducts a so-called "Structured Dialogue" on security and arms control issues in capital and expert-level formats. As the discussion in the NATO-Russia Council is limited to occasional and relatively formal meetings at ambassadorial level, the Structured Dialogue is currently the only real multilateral security dialogue in Europe. 
Measures of risk reduction of this kind aim at reducing the most immediate risks resulting from a deterrence relationship without changing the quality of this relationship or questioning it at all. Although there is a broad consensus that measures of this kind are desirable and urgent, it is not easy to achieve results. Nevertheless, direct measures of risk reduction represent only the first steps: they are necessary, but not sufficient.

A second, partially overlapping option is to increase military transparency. This concerns primarily the efforts to modernize the Vienna Document. During the German 2016 OSCE Chairmanship, dozens of proposals by NATO and neutral states were tabled. Mainly on the three issues of strengthening Chapter III (Risk Reduction), lowering the thresholds for notification and observation of certain military activities, and on increasing the number of inspections and evaluation visits. In late 2019, these proposals were retabled.

In addition to these well-elaborated proposals, it would be desirable to include all branches of armed forces in the VDi1 including coastal, air, air defence and internal security forces as well as new types of equipment such as longrange strike capabilities and also certain types of military activities currently not covered such as snap exercises.

Currently, the Russian Federation is blocking all proposals for modernizing the Vienna Document. Russia is not ready to grant more military transparency in the absence of a larger arms control package. However, it is unclear how such a package should look like.

A third option concerns the use of conventional arms control instruments for stabilizing the deterrence relationship and reducing its inherent risks. This approach does not aim at overcoming the current deterrence relationship, but at changing its quality by minimizing destabilizing elements. ${ }^{5}$ The risks of the NATO-Russia deterrence relationship are concentrated in those areas where the two camps are neighbouring, particularly in the Baltic and the Black Sea areas. Consequently, an arms control approach for stabilizing this relationship would be sub-regional in nature combining disengagement with transparency and verification measures. Taking a Baltic Sea contact zone as an example, such an approach could consist of five measures:

First, the creation of a Baltic Sea contact zone. In political terms, such a zone must be large enough to avoid perceptions that a buffer zone is being created or that smaller states are being singled out. In operational terms, it must be

5 The following section builds on a study elaborated by 17 authors from seven states (Germany, Latvia, Poland, Russia, Switzerland, Turkey, USA) in the framework of the OsCE Network of Think Tanks and Academic Institutions: Wolfgang Zellner (Co-ordinator) et al., Reducing the Risks of Conventional Deterrence in Europe. Arms Control in the NATO-Russia Contact Zones, Vienna 2018. 
large enough to cover a sufficient part of the relevant armed forces. Thus, in our example, a Baltic Sea contact zone could comprise of Estonia, Latvia, Lithuania, Poland, the part of Germany where according to the Two-Plus-Four Treaty "Foreign armed forces and nuclear weapons or their carriers will not be stationed", ${ }^{6}$ Belarus and parts of the Western Military District of Russia. Sweden and Finland should be invited to join.

Second, the limitation of relevant combat forces within this area. In more detail, this would concern a commitment to no permanent deployment of additional substantial combat forces on the territory of NATO member States (building on the related commitment contained in the 1997 NATO-Russia Founding $\mathrm{Act}^{7}$ ), and a related commitment to no permanent deployment of substantial additional combat forces in the Russian oblasts (districts) Kaliningrad and Pskov (building on the commitment contained in the 1999 CFE Final $\left.A c t^{8}\right)$. As neither of these commitments has yet been violated, a limitation of armed forces could be achieved if the NATO States and Russia reconfirmed them and agreed to a joint definition of the yet undefined term "substantial combat forces". If desired, these commitments could be completed by unilateral limitation pledges by major states, i.e. Russia or Germany.

Third, a corresponding limitation of military exercises in the contact zone. This could be seen as a measure under Chapter $\mathrm{x}$ (Regional Measures) of the VD11. In this context, it would be important to cover all kinds of armed forces and all kinds of exercises, including those not covered by the VDi1 such as those by naval, coastal, air, air defence, and internal security forces, as well as snap and parallel exercises.

Fourth, the inclusion of rapid deployment and long-range strike potentials deployed beyond the contact zone in a transparency and verification regime. Rapid deployment forces are mobile ground forces that can be quickly relocated. Long-range strike potentials represent a broad range of ballistic and

6 Treaty on the Final Settlement with Respect to Germany, in: Bundesgesetzblatt, 1990, Teil II, Nr. 38, Art. 5, p. 1324, 13 October 1990.

7 "NATO reiterates that in the current and foreseeable security environment, the Alliance will carry out its collective defence and other missions by ensuring the necessary interoperability, integration, and capability for reinforcement rather than by additional permanent stationing of substantial combat forces" (Founding Act on Mutual Relations, Cooperation and Security between NATO and the Russian Federation, signed in Paris, France, 27 May 1997).

8 "The Russian Federation will show due restraint with regard to ground TLE levels and deployments in the region which includes the Kaliningrad oblast and the Pskov oblast. In the present politico-military situation, it has no reasons, plans or intentions to station substantial additional combat forces, whether air or ground forces, in that region on a permanent basis" (Final Act of the Conference of the States Parties to the Treaty on Conventional Armed Forces in Europe, CFE.Doc/2/99, 19 November 1999, ANNEX 5). 
cruise missiles as well as air and missile defence systems. Neglecting these kinds of systems would devaluate any sub-regional arms control approach significantly. Including ship-based systems and thus naval forces into a transparency and verification system represents a challenge, as these systems are not yet covered by any European arms control regime.

And fifth and finally, a strict transparency and verification regime with a sufficient number of on-site inspections.

All these measures should be negotiated between NATO and Russia, and other interested states should be invited to join these negotiations. Agreed measures should be integrated into OSCE regimes as far as possible. This approach would have three significant advantages. On the one hand, it would address the real risks, namely sub-regional options for surprise attack. On the other, it could be mainly built on the adaptation of existing agreements - the Vienna Document, the NATo-Russia Founding Act and the CFE Final Act rather than negotiating a completely new treaty. And finally, this is a costeffective approach. It does not require any expensive reallocation of armed forces - the main investment would instead be in verification.

\section{Counterarguments against (Sub-Regional) Arms Control}

Of course, there are a number of objections to arms control with Russia under the present circumstances in general, and to sub-regional arms control specifically.

Some will say that "business as usual" with Russia is not possible and negotiating arms control agreements with Russia means rewarding Russia's bad international behaviour. However, we are going through extraordinary times that require special measures. Duly verified arms control agreements with Russia, be it existing ones such as the New START Treaty on strategic nuclear weapons or possible future ones as suggested in this essay, serve the security interests of all sides and do not represent a reward to Russia. Nevertheless, an agreement on arms control in a Baltic contact zone is difficult to imagine in the absence of the full implementations of the Minsk Agreements on the conflict in and around Ukraine.

Others will argue that a focus on arms control might divert attention from defence efforts. However, the measures proposed are designed to stabilize deterrence and to strengthen defence, not to replace it. In its whole history, arms control has never been understood as an element contradicting defence. Rather, arms control and defence have been seen as two mutually reinforcing elements of a broader security strategy. 
An objection specifically addressing sub-regional arms control is that its modus operandi is that of a "buffer zone". In an international context, a buffer zone is seen as a state or group of states, mostly smaller states, tasked with keeping apart two larger inimical states at their own expense. This would be the case if the Baltic contact zone only included the three Baltic States and possibly Poland. However, in our design, larger parts of Germany and Russia would be included as well. Thus, there is no buffer keeping two states apart.

Finally, there is the argument that any kind of European arms control is only possible if and when the U.s. agrees, and that such an agreement is hardly imaginable under the present political circumstances. This is true, but it should not be misused as a catch-all argument against any kind of (arms control) agreements with Russia. At present, conventional arms control in Europe is a NATO issue dealt with in the Alliance's High-Level Task Force (HLTF). Currently, the EU does not deal with arms control apart from nuclear non-proliferation. However, as the EU is increasingly dealing with the defence of Europe under the headline of PESCO (Permanent Structured Cooperation), it should include arms control in its agenda. A joint European position on arms control would provide more weight vis-a-vis the U.s.

Nevertheless, it will be difficult if not impossible, to agree on a new approach for arms control in Europe, if this is not part and parcel of a broader strategy vis-a-vis Russia, aimed not at cooperative security, which is not achievable at the moment, but at a status of reasonable, pragmatic co-operation. French President Emmanuel Macron outlined such an approach in a speech at the French Ambassadors' Conference on 27 August 2019:

"I believe we must build a new architecture based on trust and security in Europe because the European continent will never be stable, will never be secure, if we do not ease and clarify our relations with Russia." And: "It is about solving deadlocked conflicts on the European continent, and together rethinking conventional, nuclear, biological and chemical arms control". 9

It is by taking a broader perspective such as this that a new approach to arms control could make sense and even become necessary.

9 French Embassy to Latvia, Ambassadors' Conference, Speech by Emmanuel Macron, President of the Republic, 27 August 2019. 